\title{
Plasma levels of protachykinin-1 (TAC1) in patients with sarcoidosis
}

\author{
Sarkoidozlu hastalarda plazma protaşikinin-1 (TAC1) düzeyleri \\ Celalettin Korkmaz ${ }^{\mathbf{a}}$, Turan Akdag \\ ${ }^{\text {a }}$ Department of Pulmonary Disease, Meram Faculty of Medicine, Necmettin Erbakan University, Konya, Turkey \\ Meram Vocational School, Necmettin Erbakan University, Konya, Turkey
}

\begin{abstract}
Introduction: The etiology and pathogenesis of sarcoidosis, a systemic granulomatous lung disease affecting many people, still remain unknown. Sarcoidosis is diagnosed by demonstrating non-caseous granulomas and ruling out granulomatous diseases. Therefore, sensitive biomarkers used in diagnosis and follow-up processes are needed. Our aim is to investigate diagnostic value of plasma protachykinin-1 (TAC1) levels in sarcoidosis patients.

Methods: Forty-two sarcoidosis patients followed-up by the department of chest diseases, and 38 controls were included into the study. Clinical, radiological and laboratory data of patients were recorded, and plasma TAC1 levels were analyzed in patients and healthy controls.

Results: Plasma TAC1 levels of sarcoidosis patients and controls were found as $1124.25 \pm 1117.25 \mathrm{ng} / \mathrm{L}$ and $1319.37 \pm 1357.38 \mathrm{ng} / \mathrm{L}$, respectively. Although not statistically significant $(\mathrm{p}=0.338$ ), a decrease was found in TAC1 levels of sarcoidosis patients. Additionally, patients' lymphocyte levels were also found significantly lower than controls $(\mathrm{p}=0.007)$. No statistically significant correlation was found between other laboratory findings, including leukocyte, neutrophil, monocyte, eosinophil count, cluster of differentiation 4 (CD4) CD4 +, CD8 +, bronchoalveolar lavage (BAL) CD4 +, BAL CD8 + and neutrophil/lymphocyte ratio (NLR), and plasma TAC1 levels.

Conclusions: To the best of our knowledge, our study is the first to investigate plasma TAC1 levels as a biomarker in sarcoidosis patients. Although plasma TAC1 levels were slightly decreased in sarcoidosis patients, the decrease was not statistically significant, and no adequate data were provided for the use of plasma TAC1 level as a biomarker. We consider more comprehensive research are needed to elucidate the entity.

Key words: Sarcoidosis, lung diseases, granuloma, protachykinin, tachykinins, bronchoalveolar lavage
\end{abstract}

\section{$\ddot{O} \mathbf{z}$}

Giriş: Çok sayıda insanı etkileyebilen, sistemik granülomatöz bir akciğer hastalığı olan sarkoidozun etiyolojisi ve patogenezi hala tam olarak bilinmemektedir. Tanısı non-kazeöz granülomların gösterilmesi ve diğer granülomatöz hastalıkların dışlanmasıyla konulmaktadır. Bu nedenle tanı ve takipte kullanılabilecek hassas biyobelirteçlere ihtiyaç vardır. Bu çalışmanın amacı sarkoidozlu hastalarda plazma protașikinin-1 düzeyinin tanı değerini araştırmaktır.

Yöntem: Gögüs hastalıkları kliniğince takipli 42 sarkoidozlu hasta ve 38 kişilik kontrol grubu çalışmaya dahil edildi. Tüm hastaların klinik, radyolojik ve laboratuvar verileri kaydedildi. Sarkoidoz hastalarında ve sağlıklı kontrol grubunda plazma protaşikinin-1 düzeyleri incelendi.

Bulgular: Sarkoidoz hastalarının ve kontrol grubunun plazma protaşikinin-1 düzeyleri sırasıyla 1124.25 $\pm 1117.25 \mathrm{ng} / \mathrm{L}, 1319.37 \pm 1357.38 \mathrm{ng} / \mathrm{L}$ olarak bulundu. İstatistiksel olarak anlamlı olmamasına rağmen $(\mathrm{p}=0.338)$ sarkoidoz hastalarında protaşikinin-1 düzeyinde azalma saptandı. Ek olarak hastaların lenfosit düzeyleri de kontrol grubuna göre anlamlı olarak düşük bulundu ( $\mathrm{p}=0.007$ ). Diğer laboratuvar bulguları (lökosit, nötrofil, monosit, eozinofil sayıs1, CD4 +, CD8 +, bronkoalveoler lavaj (BAL) CD4 +, BAL CD8 +, nötrofil / lenfosit oran1) ile de plazma protașikinin-1 arasında istatistiksel olarak anlamlı korelasyon bulunmadi.

Sonuç: Literatür taramamıza göre çalışmamız sarkoidozlu hastalarda bir biomarker olarak plazma protaşikinin-1 düzeylerini araştıran ilk çalışmadır. Sarkoidozlu hastalarda plazma protaşikinin-1 düzeyi hafif azalsa da istatistiksel olarak anlamlı bulunmamış ve bir biomarker olarak kullanılabilmesi için yeterli veri sağlanamamıştır. Bu konuda daha fazla ve kapsamlı araştırmalara ihtiyaç vardır.

Anahtar kelimeler: Sarkoidoz, akciğer hastalıkları, granülom, protaşikinin, taşikininler, bronkoalveoler lavaj

\begin{tabular}{|c|c|c|c|c|}
\hline Received & Accepted & Published Online & Corresponding Author & E-mail \\
\hline August 11, 2020 & December 15, 2020 & December 18, 2020 & Celalettin Korkmaz, MD & celalettinkorkmaz@ hotmail.com \\
\hline Correspondence & $\begin{array}{l}\text { Dr. Celalettin Korkmaz, Necmettin Erbakan Üniversitesi Meram Tup Fakültesi Hastanesi Hocacihan Mah. } \\
\text { Abdulhamid Han Cad. No:3 42080 Selçuklu Konya TURKEY }\end{array}$ \\
\hline
\end{tabular}




\section{Introduction}

As a systemic granulomatous disease, sarcoidosis may affect many individuals throughout the world. As well as observing clinical, pulmonary infiltration, bilateral hilar lymphadenopathy, ocular and skin lesions in the disease, sarcoidosis may also affect the central nervous system (CNS), liver, spleen, salivary glands, heart, muscles, bones and other organs [1,2]. Sarcoidosis is known as a disease affecting individuals from all races, all age segments and both genders.

The etiology of sarcoidosis still remains unknown. In recent years, however, the interest shown to sarcoidosis has focused on the hypothesis of the abnormal immune response occurring after the exposure to an unknown infectious or environmental agent in individuals with genetic predisposition [3].

While non-caseous granulomas should be demonstrated in terms of sarcoidosis for the histopathological diagnosis, other granulomatous diseases should be ruled out through compatible clinical, biochemical and radiological findings [4]. Transbronchial biopsy, mucous biopsy, skin and lymph node sampling may performed in order to histopathological diagnose for sarcoidosis [5]. Despite higher success rate of all these modalities, some sarcoidosis patients can be ignored in terms of definitive differential diagnosis of granulomatous lung diseases. Therefore, the determination of sensitive biomarkers is very important in terms of the certain diagnosis of the disease. To date, although many diagnostic parameters have been proposed for the diagnosis of sarcoidosis, most have yet to be verified.

Tachykinin peptides, one of the largest families of neuropeptides, are characterized by a common C-terminal sequence as Phe-X-Gly-Leu-MetNH2 (FXGLM) where X is an aromatic (Phe, Tyr) or branched aliphatic (Val, Ile) amino acid [6]. The genes producing tachykinins encode the precursor proteins, and so are called preprotachykinins. Therefore, the family of tachykinins is widely distributed in both CNS and its periphery and plays a variety of biological responses in many tissues. Moreover, protachykinin-1 (TAC1) involves in many physiological process, such as potent vasodilator, neuron stimulation and behavioral responses, and has effects on various muscles [7].

The determination of protein or peptide levels in many diseases can provide an opportunity or advantage for the management, diagnosis and prognosis of the diseases [8]. In addition, it is noteworthy to determine whether TAC1 has a clinical value or potential in terms of early diagnosis. In light of literature, plasma TAC1 levels have yet to be investigated satisfactorily in sarcoidosis in previous studies, and so the present study was planned to enlighten the effect mechanism of plasma TAC1 levels in sarcoidosis.

\section{Methods}

The study was conducted with 42 sarcoidosis patients and 38 control subjects admitted to the department of chest diseases of the hospital affiliated a university between October 2019 and June 2020. The study was performed with the patients showing non-caseous necrosis based on the clinical and radiological findings. Sarcoidosis was also diagnosed by revealing epithelioid cell granulomas via the histopathological examination and with the exclusion of other disorders leading to granulomatous inflammation. Based on clinical, radiological and histopathological investigations, 67 sarcoidosis patients with final diagnosis were determined. Twenty-five patients were excluded out of the study under the exclusion criteria and missing follow-up data. Therefore, the study group was composed of 42 patients with sarcoidosis. Thirty-eight subjects with similar age- and gender-matched characteristics to sarcoidosis patients were included into the study as the healthy control group. Such features as postero-anterior (PA) chest radiographs, thorax computerized tomography (CT), hematological parameters, data of extrapulmonary involvement, consultation reports and history of the clinical course taken in outpatient clinic were recorded. The patients with any metabolic disease, cancers, rheumatological disorders, vasculitis, inflammatory bowel disease, hematological disease, autoimmune disorders, cardiovascular disease (CVD) or another pulmonary disease were excluded out of the study and control groups.

Plasma samples were centrifuged within 30 minutes at 3000xrpm for 15 minutes and kept at $-80{ }^{\circ} \mathrm{C}$ until assay. Plasma TAC1 levels were measured by enzyme-linked immunosorbent assay (ELISA) kits. The plasma protachykinin-1 (TAC1) levels were measured, and the plasma concentrations of TAC1 were analyzed by human protachykinin-1 immunoassay kits (bioassay Technology Laboratory, Shanghai, China, Catalog Number: $\mathrm{E} 3342 \mathrm{Hu}$ ). While the minimum detectable concentration (sensitivity) rate and the assay range were measured as $10.25 \mathrm{ng} / \mathrm{L}$ and $20 \mathrm{ng} / \mathrm{L}-6000$ $\mathrm{ng} / \mathrm{L}$ respectively, the intra- and inter-assay variation rates were found to be $<8 \%$ and $<10 \%$, respectively. The manufacturer's instructions were followed for the assay of the study. The absorbances of the samples were measured at $450 \mathrm{~nm}$ and recorded by absorbance microtiter plate reader (Elx800TM, Bio-Tech Instruments, USA). The present study was performed in accordance with the Declaration of Helsinki Good Clinical Practice Guidelines in 1964 and later amendments.

\section{Ethical Approval}

The study was approved by the Ethics Committee of the Medical Faculty of Necmettin Erbakan University (Date: 20/09/2019 and number: 2019/2083). Informed consent statements were obtained from all participants before the study was commenced.

\section{Statistical analyses}

All data detected in the study were analyzed with the Statistical Package for the Social Sciences software package for Windows, version 22.0 (SPSS Inc, Chicago, IL, USA). Since the data were concluded not to show a normal distribution as a result of the normality tests, the non-parametric analyzes were used. Therefore, the differences of protachykinin-1 levels between both groups were evaluated by the Mann-Whitney U test. The comparisons between protachykinin-1 levels of both groups and some laboratory parameters were determined by the Spearman's rank correlation 
test. Also, the characteristics and clinical data determined in both groups and measured plasma TAC1 levels were given as mean \pm standard deviation $(\mathrm{X} \pm \mathrm{SD}$ ). A $\mathrm{p}$ value $<0.05$ was considered to be statistically significant.

\section{Results}

Twenty-eight $(66.66 \%)$ female and $14(33.33 \%)$ male individuals with sarcoidosis constituted the study participants. The distribution of the disorders among our participants were as follows: Skin and heart involvements in four patients (9.52\%), ocular involvements in two patients (4.76\%), neurological involvements (i.e. Heerfordt syndrome, a form of neurosarcoidosis including the combination of fever, parotid gland enlargement, anterior uveitis and facial nerve paralysis) in two patients (4.76\%), and Leöfgren's syndrome (arthritis, erythema nodosum and bilateral hilar lymphadenopathy) in one patient (2.38\%). However, no extrapulmonary involvement was detected in 29 patients (69.04\%). Plasma TAC1 levels were found as $1124.25 \pm 1117.25 \mathrm{ng} / \mathrm{L}$ in the sarcoidosis patient group, while detected as $1319.37 \pm 1357.38 \mathrm{ng} / \mathrm{L}$ in the healthy control group. According to the healthy group, plasma TAC1 levels were observed to be decreased, but the difference was not statistically significant $(\mathrm{p}=0.338)$ (Table 1).

However, TAC1 levels were found to be significantly lower than the average level in two patients with the neurological involvement (Heerfordt syndrome) (612 and $807 \mathrm{ng} / \mathrm{L}$ ). No significant difference was observed in other system involvements.

The lymphocyte levels in the patients' group were also seen to be decreased, when compared to healthy control subjects ( $\mathrm{p}=0.007)$. Additionally, no statistically difference was found between the other hematologic laboratory parameters, compared to plasma TAC1 levels (Table 2).

Table 1. Comparison of plasma protachykinin-1 levels and hematologic parameters

\begin{tabular}{|c|c|c|c|}
\hline Parameters & Sarcoidosis patients $(n=42)$ & Control group $(n=38)$ & p value* \\
\hline Age (mean/years) & 53.22 & 48.60 & - \\
\hline \multicolumn{4}{|l|}{ Gender } \\
\hline Male & $14(33.33 \%)$ & $14(36.84 \%)$ & \\
\hline Female & $28(66.66 \%)$ & $24(63.15 \%)$ & - \\
\hline \multicolumn{4}{|l|}{ Extrapulmonary involvement } \\
\hline None & $29(69.04)$ & & \\
\hline Skin & $4(9.52)$ & & \\
\hline Heart & $4(9.52)$ & & \\
\hline Eyes & $2(4.76)$ & & \\
\hline Neurologic & $2(4.76)$ & & \\
\hline Lofgren & $1(2.38)$ & & \\
\hline Plasma protachykinin-1 (ng/L) & $1124.25 \pm 1117.25$ & $1319.37 \pm 1357.38$ & 0.338 \\
\hline Leukocyte count & $7443 \pm 2552.62$ & $8381.11 \pm 1808.59$ & 0.458 \\
\hline Neutrophil count & $4626.54 \pm 2084.22$ & $4865 \pm 1545.90$ & 0.743 \\
\hline Lymphocyte count & $1929.75 \pm 942.29$ & $2722.22 \pm 934.71$ & $0.007 * *$ \\
\hline Monocyte count & $616.25 \pm 268.01$ & $593.50 \pm 157.88$ & 0.590 \\
\hline Eosinophil count & $10.20 \pm 12.44$ & $159.83 \pm 120.53$ & 0.288 \\
\hline Blood CD4 ${ }^{+}$ & $32.00 \pm 10.61$ & & - \\
\hline Blood CD8 ${ }^{+}$ & $9.60 \pm 1.44$ & & - \\
\hline BAL CD4 ${ }^{+}$ & $56.50 \pm 17.49$ & & \\
\hline BAL CD8 ${ }^{+}$ & $28.83 \pm 14.80$ & & \\
\hline NLR & $2.90 \pm 1.97$ & & \\
\hline
\end{tabular}

BAL: Bronchoalveolar lavage, CD4 $4^{+}$: Cluster of differentiation 4, CD8 ${ }^{+:}$Cluster of differentiation 8, NLR: Neutrophil/lymphocyte ratio, *Descriptive statistics, Mann-Whitney U test, **p value $<0.05$ was considered to be statistically significant. 
Table 2. Comparison of the laboratory parameters according to plasma protachykinin-1 levels

\begin{tabular}{lcc}
\hline \multicolumn{1}{c}{ Laboratory Parameters } & \multicolumn{2}{c}{ Protachykinin-1 } \\
\hline Leukocyte count & r & p \\
Neutrophil count & 0.120 & 0.461 \\
Lymphocyte count & 0.191 & 0.239 \\
Monocyte count & $-0,079$ & 0.627 \\
Eosinophil count & $-0,073$ & 0.987 \\
CD4 $^{+}$ & $-0,062$ & 0.798 \\
CD8 $^{+}$ & 0,115 & 0.742 \\
BAL CD4+ $_{\text {BAL CD8+ }}$ & 0,086 & 0.200 \\
NLR & 0,054 & 0.211 \\
\hline
\end{tabular}

BAL: Bronchoalveolar lavage, CD4+: Cluster of differentiation 4, CD8+: Cluster of differentiation 8, NLR: Neutrophil/lymphocyte ratio, r: Correlation coefficient, * Correlation analyses, Spearman's rank correlation, and a p value $<0.05$ was considered to be statistically significant.

\section{Discussion}

Most commonly involving the lungs, sarcoidosis may also show different involvements in many organs. The involvements of different organs observed in our study were as follows: Skin in four (9.52\%) patients, heart in four (9.52\%), eyes in two (4.76\%), neurologic in two (4.76\%) and Lofgren in one (\% 2,38) patient. However, no extrapulmonary involvements were determined in 29 (69.04\%) participants. Sarcoidosis was first described by the dermatologist Jonathan Hutchinson in 1877 as a disorder presenting with severe skin lesions called as "sarcoid" [9]. The most commonly involved organs are the lungs (>90\%), followed by the skin and eyes [10].

In previous reports, it is stated that sarcoidosis may occur at any age, and the onset of the disease is most common, especially between 20-50 years of age. Considering the ethnic and gender differences, women are also seen as the more affected gender in all age segments and ethnic groups [11]. In our study, of 42 sarcoidosis patients, mean age rate was found as 53.2 years, and $28(66.66 \%)$ participants were seen to be women.

From immunologic viewpoint, sarcoidosis is defined through such parameters as the increase in Thelper cell/T suppressor lymphocyte ratio in the disease region, the accumulation of Th-1 cells in the activity region, and the increase in B lymphocytes and circulating immune complex activity [12]. In the granulomatous inflammation, T cells are regulated by the complex relations of mononuclear phagocytic cells, fibroblasts, dendritic cells and other helper cells. Also, cytokines released from these cells have important effects on the formation of inflammation. Granulomatous inflammation leads to local tissue damage, disrupts the normal structure and produces pathological changes in the functions of organs through cytokines and mediators $[9,13]$.

Tachykinins are widely distributed in both CNS and its periphery and play a variety of biological responses in many tissues. Moreover, TAC1 involves in many physiological processes, such as potent vasodilator, neuron stimulation and behavioral responses, and shows some effects on various muscles [7]. As well as inducing the vasodilation and contraction of airway smooth muscles, the tachykinin family also plays a role in the pathophysiology of chronic inflammatory airway diseases, such as bronchial asthma [14]. The prominent respiratory tachykinins, substance $\mathrm{P}$ and neurokinin A are primarily released from sensory nerve fibers, and believed to mediate the excitatory non-adrenergic, non-cholinergic (NANC) effects on the nervous system. However, it is difficult to put such a nervous system into a classification at the pharmacological, neurophysiological and neurochemical levels without paying attention to a large number of specific differences. It is widely accepted that tachykinins exhibit the proinflammatory peptides released from airway nerve terminals through the mechanical and chemical stimuli [15]. In one of the recent study where the same issue was investigated by Tillmaand et al., the peptide contents of dorsal root ganglia (DRG) and dorsal horn (DH) tissues were analyzed in the chronic itching rat models created in order to investigate the roles of neuropeptides in transmitting itching signals. In previous studies, 30 peptides, such as proenkephalin-A, proSAAS, protein AF1q, secretogranin-1, thioredoxin and calcitonin gene-related peptide have been detected at measurable level so far, one of which is TAC1 [16]. In the present study, plasma TAC1 levels of sarcoidosis patients and healthy control subjects were found as $1124.25 \pm 1117.25 \mathrm{ng} / \mathrm{L}, 1319.37 \pm 1357.38 \mathrm{ng} / \mathrm{L}$, respectively. Although there were no statistically significant differences ( $\mathrm{p}=0.338$ ), a minimal decrease was determined in plasma TAC1 levels in the patient group, compared with the healthy control subjects (Table 1). However, 
plasma TAC1 levels of the two patients with neurological involvements (Heerfordt Syndrome) were found to be significantly lower than the mean value found in the patients with sarcoidosis and that of the control group (612 ng/L and $807 \mathrm{ng} / \mathrm{L}$, respectively). Such a finding also suggests that sarcoidosis may display a negative correlation with the neurological involvement in the studies including larger populations. A previous study performed by Bleier reports an association between allergic rhinitis and ocular symptoms. In the study, a mouse model was created to study the naso-ocular interaction in allergic rhinoconjunctivitis, and it was found that increased levels of inflammatory mediators were present in both the conjunctiva and trigeminal ganglion. Furthermore, the treatment with a mast cell activator caused the levels of substance $\mathrm{P}$ and beta hexosaminidase levels to increase in the conjunctiva and plasma TAC1 levels in the trigeminal ganglia. However, these levels were seen to decrease after the use of a mast cell stabilizer or destruction of the sensory nerves [17]. The decrease seen in TAC1 levels after the destruction of sensorial nerves also support our consideration.

In the 1960s and early 1970s, the observation of lymphopenia and cutaneous anergy in the peripheral blood [delayed hypersensitivity to antigens, such as purified protein derivative (PPD) and lack of skin reactions] suggested that sarcoidosis was due to the deficiency of T cells [3]. Similarly, in our study, it was found that lymphocyte levels decreased in patients with sarcoidosis compared to healthy controls $(p=0.007)$. Also, no statistically difference was found between plasma TAC1 levels and other laboratory parameters of the sarcoidosis patients in our study (Table 2).

\section{Limitations}

The present study was performed only in a single province, and the number of study population was limited. For this reason, the study findings cannot be generalized to the other regions of Turkey, and more comprehensive studies with larger populations are needed to shed light on the entity.

\section{Conclusion}

There are requirements for novel specific biomarkers of high sensitivity and specificity in diagnosing sarcoidosis, predicting its clinical course and managing the clinical decisions as to this disorder. Our study demonstrated that plasma concentrations of TAC1 displayed similar values in sarcoidosis patients to those in the healthy control subjects. Based on the literature, we consider that our study provided an insight into the determination of plasma TAC1 levels in those with sarcoidosis.

\section{Conflict of interest: None.}

\begin{tabular}{|l|l|l|}
\hline \multicolumn{2}{|l|}{ Author Contributions } & Author Initials \\
\hline SCD & Study Conception and Design & CK, TA \\
\hline AD & Acquisition of Data & CK, TA \\
\hline AID & Analysis and Interpretation of Data & TA, CK \\
\hline DM & Drafting of Manuscript & TA, CK \\
\hline CR & Critical Revision & CK, TA \\
\hline
\end{tabular}

Financial support: None.

Acknowledgement: Authors thank Numan Duran for language editing.

\section{References}

1. Jones N, Mochizuki M. Sarcoidosis: epidemiology and clinical features. Ocul Immunol Inflamm 2010;18(2):72-9. https://doi.org/10.3109/09273941003710598

2. Iannuzzi MC, Rybicki BA, Teirstein AS. Sarcoidosis. N Engl J Med 2007;357(21): 2153-65. https://doi.org/10.1056/NEJMra071714

3. Grunewald J, Grutters JC, Arkema E V, Saketkoo LA, Moller DR, Müller QJ. Sarcoidosis. Nat Rev Dis Primers 2019;5(1):45. https://doi.org/10.1038/s41572-019-0096-X

4. Lazarus A. Sarcoidosis: epidemiology, etiology, pathogenesis, and genetics. Dis Mon 2009;55(11):649-60. https://doi.org/10.1016/j.disamonth.2009.04.008

5. Nazarullah A, Nilson R, Maselli DJ, Jagirdar J. Incidence and aetiologies of pulmonary granulomatous inflammation: a decade of experience. Respirology 2015;20(1):115-21. https://doi.org/10.1111/resp.12410

6. Helke CJ, Krause JE, Mantyh PW, Couture R, Bannon MJ. Diversity in mammalian tachykinin peptidergic neurons: multiple peptides, receptors, and regulatory mechanisms. Faseb J 1990;4(6):1606-15. https://pubmed.ncbi.nlm.nih.gov/1969374/ 
7. Maggio JE. Tachykinins. Annu Rev Neurosci 1988;11:13-28. https://doi.org/10.1146/annurev.ne.11.030188.000305

8. Dwivedi S, Purohit P, Misra R, Pareek P, Goel A, Khattri S, et al. Diseases and molecular diagnostics: a step closer to precision medicine. Indian J Clin Biochem 2017;32(4):374-98. https://doi.org/10.1007/s12291-017-0688-8

9. Statement on sarcoidosis. Joint Statement of the American Thoracic Society (ATS), the European Respiratory Society (ERS) and the World Association of Sarcoidosis and Other Granulomatous Disorders (WASOG) adopted by the ATS Board of directors and by the ERS Executive Committee, February 1999. Am J Respir Crit Care Med 1999;160(2):736-55. https://doi.org/10.1164/ajrccm.160.2.ats4-99

10. Ahmadzai, H., Huang, S., Steinfort, C., Markos, J., Allen, R. K., Wakefield, D., et al., Sarcoidosis: a state of the art review from the Thoracic Society of Australia and New Zealand. Med J Aust 2018;208(11):499-504. https://doi.org/10.5694/mja17.00610

11. Arkema EV, Cozier YC. Epidemiology of sarcoidosis: current findings and future directions. Ther Adv Chronic Dis 2018;9(11):227-40. https://doi.org/10.1177\%2F2040622318790197

12. Moller DR. Systemic sarcoidosis. Fishman's pulmonary diseases and disorders. 1998:1125-42.

13. Timmermans WM, Van Laar JA, Van Hagen PM, Van Zelm MC. Immunopathogenesis of granulomas in chronic autoinflammatory diseases. Clin Transl Immunol 2016;5(12):e118. https://doi.org/10.1038/cti.2016.75

14. Fischer A, Mc Gregor GP, Saria A, Philippin B, Kummer W. Induction of tachykinin gene and peptide expression in guinea pig nodose primary afferent neurons by allergic airway inflammation. J Clin Invest 1996;98(10):2284-91. https://doi.org/10.1172/JCI119039

15. Groneberg DA, Harrison S, Dinh QT, Geppetti P, Fischer, A. Tachykinins in the respiratory tract. Curr Drug Targets 2006;7(8):1005-10. https://doi.org/10.2174/138945006778019318

16. Tillmaand EG, Anapindi KDB, De La Toba EA, Guo CJ, Krebs J, Lenhart AE, et al. Quantitative characterization of the neuropeptide level changes in dorsal horn and dorsal root ganglia regions of the murine itch models. J Proteome Res 2020;19(3):1248-57. https://doi.org/10.1021/acs.jproteome.9b00758

17. Bleier B. Editorial: Blending medical and surgical therapies to optimize patient outcomes in chronic rhinosinusitis and allergic rhinitis. Am J Rhinol Allergy 2014;28(4):279-80. https://doi.org/10.2500\%2Fajra.2014.28.4089 